\title{
Establishing a Valid, Reliable Measure of Writing Apprehension for Japanese Students
}

Steve Cornwell

Osaka Jogakuin Junior College

\section{Tonia McKay}

Osaka Jogakuin Junior College

A large body of research deals with anxiety in foreign or second language learning. However, little research has been conducted on anxiety as it pertains to foreign or second language writing. The limited amount of research that does exist utilizes Daly and Miller's Writing Apprehension Test (DM-WAT), a questionnaire designed for first language (L1) writing students. Until recently, no attempts have been made to validate the questionnaire for a second language (L2) population. This paper reports on our attempts to validate a translated DMWAT for Japanese students of English. A valid measure of L2 writing apprehension could identify at-risk writers, predict academic success in writing, and present benchmarks against which to measure the' success of treatments designed to lower writing apprehension. Initial results seem to indicate that a translated, modified version of the DM-WAT is a valid measure of writing apprehension for Japanese junior college students of English.

外国語、もしくは第二言語学習に㧍ける不安感（anxiety）については、多くの研究がな されているが、ライティングに関しては、anxiety に関する研究がほとんどない。わずかに 記録されている研究は、英語を母国語にする学習者用につくられた『デイリーとミラーに よるライティング不安感テスト（DM-WAT)」を使ったものである。ごく最近までこのテス トを、英語を第二外国語とするグループに適用することは、試みられていなかった。

この論文では、日本人の英語学習者向けに翻訳したDM-WATの、適用の試みについて報 告する。第二言語でのライティングにおいて、学習者が経験する不安感を適正に測定する ことにより、ライティングに問題のある学習者をさがしだし、またどうすれば優れたライ ティングができるかを示す。さらにはライティングの不安感をやわらげる対策をたてるに あたっての、指標を示すことができる。翻案版DM-WATを日本の短大英語学習者に試みた ところ、第一段階としては適正な結果が得られた。 
ast research on anxiety in foreign or second language (L2) learning indicates that anxiety can have a negative effect on learners. Research has suggested that learners' performance (Kleinmann, 1977; Horwitz, Horwitz, \& Cope, 1986; Steinberg \& Horwitz, 1986), participation (Ely, 1986), course grades (Horwitz, 1986; Horwitz, Horwitz, \& Cope, 1986), cognitive processing (Krashen, 1982; MacIntyre \& Gardner, 1994b), and motivation (Ely, 1986) can be negatively affected by anxiety. Most research on L2 anxiety has focused on classroom speaking and listening situations. However, very little attention has been paid to anxiety as it pertains to L2 writing. The research that does exist has borrowed from first language (L1) research, namely from Daly and Miller's (1975a) research on the construct they name "writing apprehension," which Daly defines as "the fear or anxiety an individual may feel about the act of composing written material" (1991, p. 3).

Daly and Miller (1975a; 1975b) developed and validated a 26-item self-report writing apprehension test (the DM-WAT) which purports to measure the degree of anxiety an individual experiences when faced with the task of writing in the L1. The DM-WAT has also been used to some extent in $\mathrm{L} 2$ research, but no attempts have been made to validate it for use with L2 learners, and it has only recently been translated into second language learners' L1. To our knowledge, no other measure exists to measure anxiety in L2 writing. However, if successfully developed, a valid and reliable measure of L2 writing apprehension could identify at-risk writers, predict academic success in L2 writing, and present benchmarks against which to measure treatments designed to lower writing apprehension. It could also offer a way to compare writing apprehension in learners' writing in their L1 and L2.

This study describes our attempts to validate the DM-WAT in Japanese for Japanese students of English. We will first discuss the literature on anxiety in second and foreign language learning before examining subsequent studies on both L1 and L2 writing apprehension. Finally, we will describe the process of validating the translated DM-WAT and report on its reliability.

\section{Research on Anxiety}

\section{L2 Research on Anxiety}

A large body of research has described multiple sources of language anxiety. One source of anxiety is the language learning experience itself. Horwitz et al. (1986) maintain that foreign language anxiety is a unique phenomenon, distinguishable from anxiety in other academic situations because of the uniqueness of the language learning process. The learner, 
fully competent in the L1, suddenly experiences a limited range of communicative choices. In a review of the literature on anxiety and language learning, MacIntyre and Gardner (1991) suggest that other factors besides anxiety, such as language aptitude and motivation, play a major role in a learner's early experiences with the foreign language (FL). In the early stages, while learners may experience anxiety, it may not necessarily be FL anxiety. Macintyre and Gardner suggest that FL anxiety tends to appear later in the learning process as a result of attitudes developed from negative experiences with the FL. This indicates that FL anxiety is not so much inherent as attributable to the learning environment.

Learners' perceptions of their ability and expectations about how they should perform are also sources of FL anxiety. In a study of learners of French, MacIntyre, Noels, and Clement (1997) found correlations among perceived L2 competence, L2 anxiety, and actual L2 competence. Anxious students tend to underestimate their competence, whereas less anxious students tend to overestimate their competence. Horwitz et al. (1986) and Horwitz (1988) report that many learners have a preconceived idea that anything uttered in a foreign language class must be completely correct, thus making oral classroom situations quite anxiety-provoking.

Oral classroom activities in general appear to cause anxiety. Mejias, Applbaum, Applbaum, and Trotter (1991) found that having to speak in front of the class was the most anxiety-provoking situation for language learners. Similarly, Koch and Terrell (1991) found that oral presentations, skits, oral quizzes, and being asked to respond caused anxiety. Bailey (1983) suggests that competitive situations cause anxiety. In all of these situations learners are apt to compare themselves to others (Young, 1990). Hembree (1988) reports on testing situations and anxiety, suggesting that learners with higher ability have lower test anxiety whereas testing situations cause anxiety for students with lower ability. Thus there appear to be various causes for language anxiety.

A large body of literature deals with the effects anxiety can have on language learning. However, MacIntyre (1995) points out that the effects of anxiety are not always negative. Anxiety can actually be facilitative if the language learning task is not too difficult. Nonetheless, most research on language anxiety focuses on its negative effects. One major effect of anxiety is learners' negative perception of their abilities as compared to others. Price (1991) found that anxious students believe their language skills to be lower than those of other students in their class and Tobias (1986) suggested that anxious students feel "left behind" if they perceive that the language class moves too quickly for them to master the material. 
Research also suggests that anxiety can negatively affect cognitive processing. Krashen (1982) notes that anxiety raises a learner's "affective filter," thereby making the learner emotionally unreceptive to input in the target language. MacIntyre and Gardner (1994a) consider language anxiety in the three stages of learning proposed by Tobias (1986): Input, Processing, and Output. These researchers developed an anxiety scale to measure anxiety at each of Tobias' three stages. The subjects of their research, first-year students of French, were asked to complete nine tasks which involved listening, comprehension, reading, and repetition, after which the subjects were asked to complete the anxiety scale. The researchers concluded that what may seem to be small effects on specific language learning skills may accumulate over time and result in obvious differences between anxious and less anxious learners. Other studies indicate that anxiety negatively influences listening comprehension (Gardner, Lalonde, Moorcroft, \& Evers, 1987) and that anxious students experience difficulty in acquiring and retrieving vocabulary (MacIntyre \& Gardner, 1989).

Finally, anxiety can negatively influence classroom behavior. One common behavior resulting from anxiety is avoidance. Anxious students tend to avoid complex grammatical constructions (Kleinmann, 1977) and difficult or personal messages in the L2 (Horwitz et al., 1986). Steinberg and Horwitz (1986) found that anxious students prefer to give concrete messages thereby avoiding interpretive messages in the L2. Anxious students also avoid volunteering answers and participating in oral classroom activities (Ely, 1986). In addition, anxiety can manifest itself in behavior that could be negatively misinterpreted by a teacher as laziness, such as coming to class unprepared, acting indifferently, missing classes, or avoiding speaking in class (Horwitz et al., 1986). Language anxiety has also been negatively correlated with course grades (Horwitz, 1986). In fact, anxious students may even over-study yet see no improvement in grades (Horwitz et al., 1986).

A recent development in $\mathrm{L} 2$ anxiety research examines whether anxiety is a causal factor in language learning or whether it is rather the result of differences in native language ability. In their linguistic coding deficits/differences hypothesis (LCDH), Sparks and Ganschow (1991, 1993a, 1993b, 1995; see also Ganschow, Sparks, Anderson, Javorshy, Skinner, \& Patton, 1994) suggest that language aptitude, not affective variables, is the main source of individual differences in foreign language achievement. Thus, ability in one's native language is more likely to influence language learning than anxiety, attitudes, or motivation. However, MacIntyre (1995) argues that LCDH reduces the role of affective variables to that of an "unfortunate side effect" (p. 90). He points to 
the significant amount of research linking anxiety to problems in second language learning, and notes that the "effects of anxiety may be more complex than has been implied by Sparks and Ganschow" (p. 96).

This debate shows some of the controversy surrounding anxiety and suggests the need for additional research on the role of anxiety in language learning, particularly in the L2 setting. However, in order to conduct such research, valid and reliable anxiety measurements must be available. Anxiety in speaking and listening classroom situations has been studied using various scales designed to measure L2 anxiety, namely the Foreign Language Classroom Anxiety Scale (FLCAS) developed by Horwitz et al. (1986), and Ely's (1986) Language Class Discomfort Scale. However, little research has been done on anxiety in writing situations, and existing research borrows heavily from Daly and Miller's (1975a) L1 research on writing apprehension.

\section{L1 Writing Apprebension Studies}

After speaking with composition teachers about the problem of students who do poorly in writing classes because of anxiety about writing, Daly and Miller (1975a) took steps to develop a valid and reliable measure of writing apprehension, the DM-WAT. They began by creating items based on then-current measurements of communication apprehension, speaking apprehension, and receiver apprehension (Heston \& Paterline, 1974; McCroskey, 1970; Wheeles, 1974). Keeping valences random to avoid any directional bias, items were developed in a number of categories including,

anxiety about writing in general, teacher evaluation of writing, peer evaluation of writing, as well as professional...evaluations. Additionally [theyl sought to provide items concerning letter writing, environments for writing, writing in tests, and self-evaluation of writing (Daly \& Miller, 1975a, p. 245).

Using these items, Daly and Miller developed a 63-item Likert-scale (5 possible responses) questionnaire and administered it to 164 undergraduate composition and interpersonal communication students. The results were submitted to Principal Component Analysis with orthogonal rotation. An eigenvalue of 1.0 was used to determine how many factors to initially extract. Factors with two items loading at .60 or higher and no secondary loading above .40 were retained. Initially a two-factor solution was generated, but it was seen that this was caused by item valences. In other words, positive factors loaded on one factor and negative factors loaded on the other factor. Therefore, a one-factor solution was generated. After dropping items that did not load above .57 and rerunning the factor analysis, Daly and Miller selected 26 items, all 
of which loaded above .60 and accounted for .46 of the variance. Next, the reliability of the instrument was tested by both split-half and testretest methods. The split-half reliability was reported at .940 , while the test-retest reliability over a week was reported at .923 . Scores were found to range from a low of 26 to a high of 130 . Daly and Miller's sample had a mean score of 79.28 with a standard deviation of 18.86. (See Appendix A for their questionnaire in English.)

Since the development of the DM-WAT, L1 research with this instrument has indicated that individuals with high levels of writing apprehension find writing to be a negative, even painful, experience and therefore avoid situations that require writing. Furthermore, individuals with high writing apprehension hesitate to enroll in nonrequired writing courses (Daly \& Miller, 1975b). They also choose occupations (Daly \& Shamo, 1976) and university majors (Daly \& Shamo, 1978) with minimal writing requirements. In addition, they have low expectations for success in writing classes (Daly \& Miller, 1975b; see also Buley-Meissner, 1989), and in fact perform less successfully than individuals with low writing apprehension (Powell, 1984; Frankinburger, 1991). For example, highly apprehensive students have been found to lack organizational strategies and tend to revise and edit less than those with low apprehension (Selfe, 1984; Bannister, 1982). They also produce shorter essays which are less developed in syntax and content (Beatty \& Payne, 1985; Faigley, Daly, \& Witte, 1981). Thus, a high level of writing apprehension places both academic and occupational restraints on an individual.

\section{Measuring Writing Apprebension in L2}

There have been few attempts to measure writing apprehension in L2 research. In two studies, Gungle and Taylor (1989) used a modified version of the DM-WAT to examine the relationship between writing apprehension and a focus on form rather than on content. The study also examined the relationships among writing apprehension and the students' willingness to take advanced writing courses, and their perceived writing requirements in their chosen majors. The modified version of the DM-WAT consisted of a 6-point rather than a 5-point Likert scale, this used to "avoid noncommittal responses" (p. 241). Gungle and Taylor also added the phrase "in English" to each statement in the DM-WAT to clarify that the statement referred only to English writing and not to writing in the students' first language. Finally, the following 3-item instrument, using an 8-point scale, was added to the bottom of the DM-WAT.

1. The English writing requirements of my major are great.

2. I would be interested in enrolling in an advanced writing class in English. 
3. When I write in English, I am more concerned with how I say something than with what I say (p. 241).

Their results showed a negative correlation between writing apprehension and students' willingness to take advanced writing courses, and a negative correlation between writing apprehension and the perceived writing requirements of their majors. There was no significant correlation between writing apprehension and a focus on forms and no significant correlation between writing apprehension and attention to content.

In their second study, Gungle and Taylor (1989) changed the 3-item instrument to the following 4-item instrument, again using an 8-point scale.

1. The English writing requirements of my major are great.

2. When writing in English I am most concerned with grammar and form.

3. I would be interested in enrolling in an advanced writing class in English.

4. When writing in English I am most concerned with content and ideas (p. 243).

The second set of results did not show a significant positive correlation between writing apprehension and concern for forms, although it showed a negative correlation between writing apprehension and concern for content.

In a pilot study, Masny and Foxall (1992) modified Gungle and Taylor's WAT, using 15 items instead of 26. They used the 4-item instrument from Gungle and Taylor's second study, replacing "The English writing requirements of my major are great" with "After this English course I will 'very often,' 'often,' 'sometimes,' 'seldom,' 'never' need to write in English" (p. 12). Their study suggested that high academic achievers had lower writing apprehension than low academic achievers. Both low and high writing apprehensive students were more concerned with forms than content. High writing apprehensive students expressed an unwillingness to take more writing classes, and females appeared to be more apprehensive than males.

As mentioned, there has been little research on L2 writing apprehension to date. Furthermore most of what has been done has shortcomings. First of all, the three studies mentioned above used questionnaires written in the subjects' L2. This is true of much $\mathrm{L} 2$ research, but may be a shortcoming. Gungle and Taylor themselves (1989) question whether their subjects could understand the modified version of the DM-WAT. They note that some of the vocabulary used "may not be entirely clear to ESL students" (p. 245), and therefore suggest that even a modified DM-WAT might be incapable of measuring L2 students' writing appre- 
hension. Both Johnson (1992, p. 114) and Brown (in preparation, p. 77) stress that students must understand any questionnaire being used, one way being administration in the students' L1. Of course this is easier to do in an EFL rather than in an ESL setting.

Finally, neither Gungle and Taylor nor Masny and Foxall (1992) report on the validity or reliability of their respective questionnaires. This is a problem in much L2 research and Griffee (1997) points out the importance for language research, especially if it is questionnaire-based, to provide this information. Without reliability and validity reports, there is no evidence that a questionnaire consistently measures what it sets out to measure.

It was not until quite recently that a study appeared using a translated version of the DM-WAT and reported on validity and reliability. Cheng, Horwitz, and Schallert (1999) examined the relationship between L2 classroom anxiety and L2 writing anxiety. They also examined relationships between L2 classroom anxiety and L2 writing anxiety with L2 speaking and writing achievement. They used the FLCAS and a modified second language version of the DM-WAT. Both instruments were translated into students' L1, Chinese, and then checked through back-translation. The DM-WAT was modified to suit the second language situation by adding the phrases "English" or "in English" to the original items to ensure that students reported on anxiety in L2 writing contexts. They also added two items, one pertaining to students' anxiety about making grammatical mistakes, and one pertaining to students' worry over their lack of ideas.

The internal consistency of the instrument was .94 using Cronbach's coefficient alpha. A factor analysis found three factors which accounted for $50.9 \%$ of the total variance. The factors were "Low Self-Confidence in Writing English," "Aversiveness of Writing in English," and "Evaluation Apprehension." The results of the study indicate that L2 writing anxiety and L2 classroom anxiety are, "two related yet relatively distinguishable anxiety constructs" (p. 436). Cheng et al. (1999) suggest that L2 writing anxiety is an anxiety which is specific to the particular language skill of writing, and L2 classroom anxiety is a more general type of anxiety with a strong emphasis on speaking anxiety.

\section{Research Focus}

Elsewhere (Cornwell \& McKay, 1997; Cornwell \& McKay, 1998) we have written on the importance writing is given at our college and the problems students face in writing. As noted, research indicates that writing anxiety can have debilitating effects on performance, participation, and self-esteem. Our goal, therefore, was to create a valid and reliable 
measurement of Japanese college students' L2 writing apprehension as a first step in addressing these problems.

Researchers have two choices when designing an attitude questionnaire: either design their own measure or replicate a preexisting measure (Converse \& Presser, 1986; Henerson, Morris, \& Fitz-Gibbon, 1987). We chose to use the DM-WAT, a preexisting measure, because it has already been used by $\mathrm{L} 2$ researchers. To address the problems of reliability and validity in questionnaire-based research, one of our goals was to validate the DM-WAT for Japanese junior college students.

By validating the DM-WAT questionnaire we could determine whether the construct of writing apprehension, documented to exist among native English-speaking college students for their L2, also exists among Japanese college students for writing in their L2, and if so, whether it exists in the same way. Development of an instrument which shows that L2 writing anxiety exists and can reliably measure such anxiety would be useful for both research and pedagogy.

\section{Research Questions}

The research questions of this study are:

1. Using the DM-WAT as a starting point, can a reliable and valid measure of Japanese junior college students' L2 writing apprehension be created in Japanese?

2. Can a reliable and valid measurement provide insight into the nature of L2 writing apprehension as it exists in Japanese junior college students?

\section{Method}

\section{Participants}

A total of 70118 to 20 year-old female students majoring in English at a private junior college in Osaka, Japan, participated in this study. The subjects were 392 first-year students enrolled in composition classes and 309 second-year students enrolled in content-based discussion and writing classes. The second-year figure also includes 30 students who were repeating the class.

\section{Materials}

As researchers have noted, translating questionnaires into the students' L1 may ensure that questions aren't misunderstood due to a lack of language proficiency. Therefore, the DM-WAT was translated into Japanese ${ }^{1}$ by a Japanese colleague (see Appendix A for the English 
version and Appendix B for the Japanese translation). In doing so, it was necessary to make some adjustments in wording to convey the original meaning. For example, if Item 2, "I have no fear of my writing being evaluated," were translated directly, it would consistently cause students to answer "incorrectly." In keeping with the original DM-WAT, however, a 5-point Likert scale was used with answers ranging from "strongly disagree" to "strongly agree."

Positive statements such as "I enjoy writing" and "Writing is a lot of fun" were reverse-scored following a formula suggested by Daly and Miller (1975a). In their article the formula was misprinted as "Writing Apprehension $=78+$ positive scores - negative scores." (1975a, p. 246). The correct formula is:

Writing Apprehension $=78$ - positive scores + negative scores.

The questionnaire was further modified by adding the phrase "in English," to make it clear that "writing" referred to writing in English (the L2), not Japanese (the L1).

Five questions were added to the end of the questionnaire. Three used a four-point Likert scale ( $4=$ very frequently; $3=$ frequently; $2=$ infrequently; $1=$ not at all) to inquire about the students' high school writing experience at the sentence, paragraph, and essay level, and two asked whether the students had studied abroad and, if so, for how long. These results will be reported elsewhere.

\section{Questionnaire Administration}

In order to guard against possible response bias caused by learning about the course writing requirements, the 15 first-year composition classes and 13 second-year Current Topic classes were given the questionnaire during the first week of the Japanese school year in April. The teachers administering the questionnaires were all native speakers of English.

\section{Data Analysis}

The data from the completed questionnaires was entered into a Microsoft Excel $5.0 \mathrm{~b}$ spreadsheet (1985-1996) and checked for accuracy. There were 48 students who left one or more of the 26 writing apprehension questions blank. Rather than lose all their data by eliminating them from the study, the missing answers were filled in with the mean value for that item, following the procedure described in Tabachnick and Fidell (1996). These authors write, "In the absence of all other information, the mean is the best guess about the value of a variable" (p. 63). The average number of answers that needed to be filled in for the 48 incomplete questionnaires was 2.7 . 
Writing apprehension scores were calculated for each student using the corrected Daly and Miller formula given earlier. The data were then imported into SPSS 6.1.1 (1989-1995), a statistical program. A factor analysis was run to help determine the underlying structure or construct(s) of the questionnaire, a step which is necessary to establish validity (Kline, 1997). First, Principal Component Analysis was run. When it indicated that there was more than one factor, a second analysis was run using Maximum Likelihood Factor Analysis with Direct Oblimin rotation, a type of oblique rotation.

\section{Reliability}

To determine the internal consistency of the questionnaire, the splithalf method was used following the description in Hatch and Lazaraton (1991). A correlation of .78 was obtained for the half test, and using the Spearman-Brown prophecy formula, the reliability of the full questionnaire was found to be $.89(N=701, M=80.08$, and $S D=12.81)$. In Daly and Miller's study, the mean score was 79.28 with a standard deviation of 18.86 . In this study, the mean was 80.08 with a standard deviation of 12.81. Kurtosis and skewness help determine whether a distribution is normal, and here kurtosis was .235 and skewness was -.021, near-zero figures which indicate a normal distribution. See Table 1 for the descriptive statistics by year.

Table 1: Descriptive Statistics for Writing Apprehension Scores:

Total, First year, Second year

\begin{tabular}{lccc}
\hline Statistic & Total & First Year & Second Year \\
\hline Mean & 80.075 & 80.634 & 79.367 \\
S.E. Mean & .484 & .605 & .784 \\
SD & 12.806 & 11.975 & 13.776 \\
Kurtosis & .235 & .292 & .132 \\
Skewness & -.021 & -.086 & .071 \\
Minimum & 38.00 & 40.00 & 38.00 \\
Maximum & 121.00 & 118.00 & 121.00 \\
$N$ & 701 & 392 & 309 \\
\hline
\end{tabular}

\section{Validity}

There are three types of validity which are often discussed in the applied linguistics research literature: content validity, criterion or predictive validity, and construct validity (Brown, in preparation; Griffee, 
1997; and Hatch \& Lazaraton, 1991). Since this study was concerned with measuring the construct of writing apprehension using an existing L1 questionnaire (the DM-WAT) administered in Japanese, we were primarily interested in construct validity. A construct is "a theoretical label that is given to some human attribute or ability that cannot be seen or touched because it goes on in the brain" (Brown, 1988, p. 103). We chose to examine construct validity through factor analysis since this procedure can determine the underlying structure or construct(s) of a questionnaire. A second purpose of factor analysis is to reduce a large number of variables to a smaller, more manageable set. According to Royce (1963, as cited in Kline, 1997), a factor is "a construct operationally defined by its factor loadings" (p. 5).

There are many ways to conduct factor analysis (see Kline, 1997, for a detailed summary of methods and procedures). Among the decisions researchers must make when doing factor analysis are: (1) how many factors to extract; (2) how to rotate the factors to obtain a final solution; (3) which variables (questions or items) to keep; and (4) how to know that a final solution has been reached. Although there are set procedures, factor analysis is a highly subjective technique since it is dependent on the researcher's interpretation of the data.

There has been considerable debate on how factors should be extracted (e.g., Kaiser criterion/ factors greater than one versus the scree test). Kline (1997) asserts that "Cattell's Scree test is just about the best solution to selecting the correct number of factors" (p. 75). In a scree test, the eigenvalues are plotted on a graph and the number of factors are determined by seeing where the line changes slope. After extracting the factors, they are then rotated to obtain maximum parsimony. An easy way to think about rotation is to think of two factors located on a graph. By rotating the $\mathrm{x}$ and $\mathrm{y}$ axes the factors change position. Rotation helps researchers identify and interpret the solution by making high factors higher and low factors lower. There are two primary methods of rotation: orthogonal, used when the factors are not believed to be correlated, and oblique, used when there is the likelihood of the factors having some correlation. Although orthogonal and oblique rotations often yield similar results (Kline, 1997), oblique rotation is more frequently used in language research (Hatch \& Lazaraton, 1991). When correlations of factors exceed .32, oblique rotation is warranted (Tabachnick \& Fidell, 1996, p. 674). After rotation a common method to determine the adequacy of rotation is to answer the question posed by Tabachnick and Fidell (1996, p. 674), "Do highly correlated variables tend to load on the same factor?" If they do, the rotation may be considered adequate. 
After determining the number of factors to retain, it is necessary to check the factor loadings. Factor loadings are the correlation of a variable with a factor. Comrey and Lee (1992, as cited in Tabachnick \& Fidell, 1996) suggest that loadings in excess of .71 (indicating $50 \%$ overlapping variance) are considered excellent, loadings of .63 (indicating $40 \%$ overlapping variance) are very good, and loadings of .55 (indicating 30\% overlapping variance) are good. Loadings of .45 (20\% overlapping variance) are fair and loadings of .32 (only $10 \%$ overlapping variance) are poor (Tabachnick \& Fidell, 1996, p. 677). Thus, variables with low factor loadings (.32 or below) should be deleted or rewritten. When looking at factor loadings it is common to see the communalities for each variable. These indicate the amount of varience that all common factors account for in each variable.

The goal of factor analysis is to achieve what is called simple structure. Simple structure refers to choosing the simplest explanation given the infinite number of rotations possible. Thurstone (1947) suggested five criteria for achieving simple structure. The most important is that, "each factor should have a few high loadings with the rest of the loadings being zero or close to zero" (p. 65). After achieving simple structure, the researcher must name the factors. This is done subjectively by looking at the specific variables loading on that factor and deciding what the underlying construct might be called.

\section{Results}

Some assumptions of factor analysis are normal distribution, large sample sizes (100 minimum), at least a 2:1 ratio of subjects to variables, and a 20:1 ratio of subjects to factors (Kline, 1997). Given the near zero values for kurtosis and skewness (statistics for testing normality) in the present data, the large sample size $(n=701)$, the use of a 26 -item questionnaire, and a four-factor solution, all of these assumptions appear to have been met in the research presented here.

Since the original Daly \& Miller study (1975a) had settled upon a onefactor solution, we began by also looking for a one-factor solution by using Principal Component Analysis, the procedure when only one factor is hypothesized. However, when it appeared that there was more than one factor, Maximum Likelihood Factor Analysis with Direct Oblimin rotation was used. An advantage of Maximum Likelihood Factor Analysis (ML) is that it, "has statistical tests for the significance of each factor as it is extracted," whereas, "other factoring methods are essentially convenient algorithms" (Kline, 1997, p. 50). Using ML, the test of fit was significant $\left(\chi^{2}=\right.$ $188.3167, \mathrm{df}=62, p<.0000)$. We chose oblique rotation because the 
correlations of several factors exceeded .32 (see Table 2). In addition, items correlating with one another also loaded on the same factor. For example, Items 2, 4, and 25 all correlate with one another at .56 or higher and all load on factor three, giving support to the adequacy of the rotation.

Table 2: Factor Correlation Matrix

\begin{tabular}{lllll}
\hline & Factor 1 & Factor 2 & Factor 3 & Factor 4 \\
\hline Factor 1 & 1.00000 & & & \\
Factor 2 & -.44427 & 1.00000 & & \\
Factor 3 & -.47141 & -.58103 & 1.00000 & \\
Factor 4 & -.44106 & -.16971 & -.28036 & 1.00000 \\
\hline
\end{tabular}

The number of factors to extract in this study was determined by comparing the scree plot to factors that had an eigenvalue of greater than one. Initially there were five factors with eigenvalues over 1.0; however, the scree plot suggested a four-factor solution. To confirm this, we also looked at three-, four- and five-factor solutions to determine the optimum solution for explaining the underlying structure and chose a four-factor solution. The eigenvalues and percent of variance are shown in Table 3.

Table 3: Eigenvalues and Percent of Variance

\begin{tabular}{ccc}
\hline Eigenvalues & Percentage of Variance & Cumulative Percentage \\
\hline 6.23370 & 39.0 & 39.0 \\
1.84783 & 11.5 & 50.5 \\
1.24915 & 7.8 & 58.3 \\
1.05170 & 6.6 & 64.9 \\
\hline
\end{tabular}

Factor loadings of .32 and above are often used to determine factors. However, in this study loadings of .32 produced several complex factors ${ }^{2}$ and low communalities, thereby presenting problems for interpretation. By changing to a more stringent .55 loading we were able to delete several items, eliminating all complex factors and achieving simple structure. Items 5, 6 to 9, 13 to 14, 18, 21, and 23 had loadings of less than .55 and were thus deleted. We ran the factor analysis again and the factor loadings and communalities are shown in Table 4. Because some of the variables were deleted, in the future a new formula for 
calculating writing apprehension must be used. That formula is:

Writing Apprehension $=64$ - positive scores + negative scores.

Here scores can range from a low of 2 to a high of 90 .

Table 4: Factor Loadings and Communalities

\begin{tabular}{llllll}
\hline & Factor 1 & Factor 2 & Factor 3 & Factor 4 & Communalities \\
\hline Q15 & .84069 & & & & .71591 \\
Q17 & .78095 & & & .62560 \\
Q03 & .67349 & & & .46583 \\
Q10 & .67274 & & & .46640 \\
Q01 & -.54891 & & & .38688 \\
Q02 & & .81627 & & & \\
Q04 & & .81060 & & .67900 \\
Q25 & & .70704 & & .66182 \\
Q26 & & & .78165 & & .65281 \\
Q24 & & & .70357 & & .63332 \\
Q11 & & & -.65312 & .51113 \\
Q22 & & .63922 & .47677 \\
Q16 & & .63169 & .43598 \\
Q20 & & & .42466 \\
Q19 & & & .77300 & .61754 \\
Q12 & & & .65274 & .47124 \\
\hline
\end{tabular}

Note: Factor loadings less than .55 are not shown with the exception of question $01,-.54891$.

Table 5 shows the items that loaded on each factor along with the percentage of students choosing each answer. Deleted items (items that loaded at less than .55) are shown in italics.

The first factor included five items and accounted for $39.0 \%$ of the variance. We labeled this factor Enjoyment of Writing. Representative items are Item 15, "I enjoy writing," and Item 17, "Writing is a lot of fun."

Factor two consisted of three items which had loadings above .70. It accounted for $11.5 \%$ of the variance. This factor was labeled Fear of Evaluation and included Item 4, "I am afraid of writing essays when I know they will be evaluated," and Item 25, "I don't like my compositions to be evaluated." This factor seems to address evaluation in a classroom situation. 


\section{Table 5: Questions Arranged According to Factors with Percentages of Answers}

Likert Scale Items*
Factor One: Enjoyment of Writing
15. I enjoy writing.

17. Writing is a lot of fun.

3. I look forward to writing down my ideas.

10. I like to write my ideas down.

1. I avoid writing.

8. Expressing ideas through writing seems to be a waste of time. ${ }^{* *}$

\section{Factor Two: Fear of Evaluation}

2. I have no fear of my writing being evaluated.

4. I am afraid of writing essays when I know they will be evaluated.
25. I don't like my compositions to be evaluated.
11.1
8.3
5. Taking a composition course is a very frightening experience.

A $\quad \mathrm{U}$

D SD

$\begin{array}{lllll}2.0 & 6.1 & 11.6 & 46.9 & 33.4\end{array}$

Factor Three: Negative Perceptions about Writing Ability
26. I'm no good at writing.
21.0
42.0
$19.5 \quad 16.0$
1.6
24. I don't think I write as well as most other people.
$18.3 \quad 45.3$
24.1
11.1
1.3
11. I feel confident in my ability to clearly express my ideas in writing.

22. When I hand in a composition I know I'm going to do poorly.

$\begin{array}{lllll}.6 & 5.0 & 25.8 & 42.3 & 26.1\end{array}$

16. I never seem to be able to clearly write down my ideas.

$\begin{array}{lllll}7.0 & 20.0 & 38.1 & 30.5 & 4.4\end{array}$

\section{$\begin{array}{lllll}15.0 & 37.5 & 20.3 & 24.0 & 3.3\end{array}$}

21. I have a terrible time organizing my ideas in a composition course.

$\begin{array}{lllll}19.5 & 46.1 & 18.5 & 14.8 & 1.0\end{array}$

7. My mind seems to go blank when I start to work on a composition.
23. It's easy for me to write good compositions.
$\begin{array}{ll}4.6 & 19.3\end{array}$
$14.7 \quad 49.8$
11.7
.32 .9
$8.4 \quad 52.5$
35.9

18. I expect to do poorly in composition classes even before I enter them.

13. I'm nervous about writing.

$\begin{array}{lll}7.7 & 25.2 \quad 40.6\end{array}$

21.3

5.1

Factor Four: Showing My Writing to Others

$\begin{array}{lllll}11.8 & 35.1 & 19.6 & 27.4 & 6.1\end{array}$

20. Discussing my writing with others is an enjoyable experience.

$\begin{array}{lrrrrr} & 6.1 & 30.0 & 35.8 & 24.1 & 4.0 \\ \text { 19. I like seeing my thoughts on paper } & 6.4 & 32.2 & 40.4 & 17.7 & 3.3 \\ \text { 12. I like to have my friends read what I have written. } & 2.6 & 14.6 & 24.4 & 45.0 & 13.6 \\ \text { 14. People seem to enjoy what I urite. } & .6 & 3.4 & 49.6 & 31.6 & 15.1\end{array}$

9. I would enjoy submitting my writing to magazines for evaluation and publication.

\begin{tabular}{|c|c|c|c|c|c|}
\hline & 1.0 & 7.6 & 35.9 & 37. & 17.7 \\
\hline Handing in a composition makes me feel good. & 5.8 & 24.3 & 208 & & \\
\hline
\end{tabular}

*SA = Strongly Agree; $\mathrm{A}=$ Agree; $\mathrm{U}=$ Uncertain; $\mathrm{D}=$ Disagree; $\mathrm{SD}=$ Strongly Disagree

** Questions in italics were deleted from the final four-factor solution. 
Five items loading on the third factor accounted for $7.8 \%$ of the variance. Examples of items included in this factor include Item 24, "I don't think I write as well as most other people," and Item 26, "I'm no good at writing." This factor was labeled Negative Perceptions about Writing Ability and appears to tap students' perceptions about their ability to succeed in writing and to complete work in a writing class. One item, Item 11, "I feel confident in my ability to clearly express my ideas in writing" loaded negatively on this factor, meaning that it measures the other end of the scale, the student's positive perceptions of their ability.

There were three items included in factor 4 which was labeled Showing My Writing to Others. Factor 4 accounted for $6.6 \%$ of the variance. Some examples are Item 12, "I like to have my friends read what I have written," and Item 20, "Discussing my writing with others is an enjoyable experience." This factor is concerned with sharing writing with others, not necessarily for formal evaluation.

\section{Discussion}

Our study found four factors dealing with L2 writing anxiety while Daly and Miller (1975a) found only one factor. Why was there a difference? To answer this, it is necessary to examine how the two questionnaires were created. Daly and Miller followed the normal stages in instrument development. They spoke with high school and college composition teachers prior to developing items. The items they developed were modeled on existing communication anxiety measures. They subdivided their items into several categories such as general anxiety, teacher evaluation anxiety, peer evaluation anxiety, and professional evaluation anxiety. After running factor analysis and refining their instrument, they then used the instrument and were able to demonstrate its predictive ability.

However, we started with their questionnaire, which we had translated into Japanese. We then administered and analyzed it, refining the instrument by dropping items that did not have high loadings. One reason for the difference in number of factors might be the difference in the subjects of the respective studies: United States college students versus Japanese college students. Since one's culture can influence the rhetorical patterns one chooses (Kaplan, 1966; Brown, 1994), perhaps the way writing apprehension manifests itself differs according to culture. This is an important area for future research.

Another reason for multiple factors in these results is that this study is concerned with anxiety occurring when writing in the L2, whereas Daly and Miller were looking at writing anxiety in the L1. Anxiety may differ according to the language in which writing takes place. A third reason 
may relate to the different eras of the tests. Daly and Miller administered their questionnaire in 1974 and we administered ours in 1997. Over the last twenty years writing instruction has evolved by moving from a rhetorical-based approach emphasizing the product to a process approach which incorporates peer evaluation. (For a review of the history of second language writing instruction see Silva, 1990.) In 1974, the concept of "showing one's writing to others" may have involved seeking out a friend for informal response. However, for our second-year students in 1997, "showing one's writing to others" implies an organized system of peer evaluation in which each student's composition is read by three other students and written comments are offered.

In their questionnaire Daly and Miller concentrated heavily on writing evaluation, whether by teachers, peers, or professionals. Thus, their construct might more appropriately be named writing evaluation anxiety. Our subjects had little or no experience with professional evaluation and most of our first-year students $(n=392)$ had no experience with L2 academic writing classes. Therefore, their answers were speculative at best. Converse and Presser (1986) ask rhetorically, "If we ask a hypothetical question, will we get a hypothetical answer" (p. 23). Responding to hypothetical questions is a difficult task for subjects and this could be part of the reason why many of the deleted questions did not load on any factor. Five of the ten deleted questions dealt with L2 composition classes.

That anxiety in foreign language learning might load on more than one factor has some support from other research in applied linguistics. Aida's (1994) study found four factors (Speech Anxiety and Fear of Negative Evaluation, Fear of Failing the Class, Comfortableness in Speaking with Native Japanese, and Negative Attitudes toward Japanese Class), two of which were similar to the factors we found. Cheng et al. (1999) found three factors (Low Self-Confidence in Writing English, Aversiveness of Writing in English, and Evaluation Apprehension), all of which are similar to the factors that we found.

Thus, considering that the DM-WAT has been used in L2 writing apprehension research and that other measures of L1 anxiety have been used in the construction of foreign language anxiety measures, we feel that using the DM-WAT is warranted. Furthermore, the items which were retained all seem to have face validity; that is, they seem to measure the factor they have been assigned to. Finally, it is important to remember that validity does not reside in questions or instruments, but is something that must be established with each administration (Griffee, 1997).

Since we chose the DM-WAT, a questionnaire dealing with an existing construct, should we have used Confirmatory Factor Analysis (CFA) rather 
than exploratory factor analysis (EFA)? CFA looks at previous studies or existing theory and tries to predict factor loadings on hypothetical variables. Its value lies in testing hypotheses. On the other hand, EFA, as Kline (1997) points out, "is ideal where data is complex and it is unclear what the most important variables in the field are" (p. 10). Unfortunately, as Kim and Mueller (1978) note, the division between the two functions is not always distinct. We did not have a hypothesis about what components make up the construct of L2 writing apprehension and the only theory that existed was for L1, not L2. Therefore, we chose to use EFA to investigate Japanese college students' L2 writing apprehension.

The validation process would have been stronger if we had backtranslated the questionnaire to ensure that the meaning of the original items in English had not changed. Also, correlating our measure with an existing measurement of anxiety, such as the FLCAS, would have strengthened the process. Finally, predicting our students' performance in L2 writing class through our instrument's writing apprehension score, then using correlational analysis to examine the apprehension scores' relationship to L2 proficiency gains achieved by the end of the year would have added strength to validity claims. This is an additional area for future research.

\section{Conclusion}

Anxiety has been shown to affect the choices students make and their ability to perform in language classrooms. It has caused students to be misdiagnosed as indifferent, unprepared, or lazy. Anxiety is clearly an issue affecting many language learners.

The multiple factors found in this study suggest that the construct of L2 writing apprehension in Japanese junior college students is more complex than that which was found in studies using the original DMWAT. In addition, other studies of foreign language anxiety have also found multiple factors, suggesting that there may be a difference between anxiety in L1 and in L2. Daly and Miller's instrument appears to have been valid in 1974 for the measurement of anxiety in a sample from the U.S. college student population. However, our instrument wss designed to measure Japanese college students' writing apprehension in the late 1990 s, when writing instruction pedagogy had changed from that used 20 years earlier.

We have noted Griffee's (1997) warning that validity does not reside in an instrument, nor is it something that is awarded to an instrument for all time (1997). In addition, research that uses translated question- 
naires must be viewed with caution. Translated questionnaires must be treated as new instruments which must go through their own validation process (Griffee, 1998). If one thing can be stressed from this study, it is that measures must be validated for new participant populations each time they are used.

\section{Acknowledgments}

The authors would like to thank. Eiko Kato for translating the questionnaire into Japanese, and Akiko Katayama for translating the abstract into Japanese. The authors would also like to thank two anonymous reviewers for their helpful suggestions.

Steve Cornwell, M.A.T., TESOL, is a doctoral student at Temple University Japan. In addition to writing apprehension, his research interests include L1 use in discussion classrooms, the nature of online learning, and junior college students' development of their sense of identity. Comments may be sent to <stevec@gol.com>.

Tonia McKay, M.A., TESOL, coordinates the Academic Writing program at Osaka Jogakuin Junior College. Her research interests include affective variables in L2 writing and the development of peer evaluations in writing and discussion courses.

\section{Notes}

1. We were not able to have the questionnaire back-translated. It took longer than we expected to receive a copy of the original Daly and Miller study so we only had two weeks before the start of the semester to prepare the translation. In addition, we wanted to administer the questionnaire at the beginning of the semester before students learned about the course requirements. By doing so we hoped their anxiety would not be affected. Finally, we wanted to administer the translated DM-WAT in the same semester that the students would take the Test of Written English (TWE).

2. A complex factor occurs when a variable loads highly on more than one factor, thereby making it difficult to identify the underlying construct.

\section{References}

Aida, Y. (1994). Examination of Horwitz, Horwitz and Cope's construct of foreign language anxiety: The case of students of Japanese. The Modern Language Journal, 78 (2), 155-168.

Bailey, K. M. (1983). Competitiveness and anxiety in adult second language learning: Looking at and through the diary studies. In $\mathrm{H}$. W. Seliger \& M. H. Long. (Eds.), Classroom oriented research in second language acquisition (pp. 67-102). Rowley, MA: Newbury House.

Bannister, L. A. (1982). Writing apprehension and anti-writing: A naturalistic study of composing strategies of college freshman. Dissertation Abstracts International, 43.

Beatty, M. J., \& Payne, S. (1985). Is construct differentiation loquacity? A motiva- 
tional perspective. Human Communication Research Journal, 11 (4), 605-612. Brown, H. D. (1994). Teaching by principles: An interactive approach to language pedagogy. Englewood Cliffs, NJ: Prentice Hall Regents.

Brown, J. D. (1988). Understanding research in second language learning: A teacher's guide to statistics and research design. New York: Cambridge University Press.

Brown, J. D. Using surveys in language programs. (Manuscript in preparation). Buley-Meissner, M. L. (1989). Am I really that bad? Writing apprehension and basic writers. Journal of Basic Writing, 8 (2), 3-20.

Cheng, Y., Horwitz, E., \& Schallert, D. (1999). Language anxiety: Differentiating writing and speaking components. Language Learning, 49 (3), 417-446.

Comrey, A., \& Lee, H. (1992). A first course in factor analysis. (2nd ed.) Hillsdale, NJ: Erlbaum.

Converse, J. M., \& Presser, S. (1986). Survey questions: Handcrafting the standardized questionnaire. Thousand Oaks, CA: Sage Publications, Inc.

Cornwell, S., \& McKay, T. (1997). Measuring writing apprehension at Osaka Jogakuin Junior College. Osaka Jogakuin College Kiyo, 27, 85-96.

Cornwell, S., \& McKay, T. (1998). Making the transition from writing short essays to long research papers. The Language Teacher, 22 (4), 15-20.

Daly, J. A. (1991). Understanding communication apprehension: An introduction for language educators. In E. K. Horwitz \& D. J. Young (Eds.), Language anxiety: From theory and research to classroom implications (pp. 3-13). Englewood Cliffs, NJ: Prentice Hall.

Daly, J. A., \& Miller, M. D. (1975a). The empirical development of an instrument to measure writing apprehension. Research in the Teaching of English, 9, (3), 242-249.

Daly, J. A., \& Miller, M. D. (1975b). Further studies on writing apprehension: SAT scores, success expectations, willingness to take advanced courses, and sex differences. Research in the Teaching of English, 9 (3), 250-253.

Daly, J. A., \& Shamo, W. G. (1976). Writing apprehension and occupational choice. Journal of Occupational Psychology, 49, 55-56.

Daly, J. A., \& Shamo, W. G. (1978). Academic decisions as a function of writing apprehension. Research in the Teaching of English, 12 (2), 119-126.

Ely, C. M. (1986). An analysis of discomfort, risk taking, sociability, and motivation in the L2 classroom. Language Learning, 36 (1), 1-25.

Faigley, L., Daly, J. A., \& Witte, S. P. (1981). The role of writing apprehension in writing performance and competence. Journal of Educational Research, 75 (1), 16-21.

Frankinburger, P. (1991). An annotated bibliography of the literature dealing with the effects of student attitude and teacher behaviors on writing apprehension and composition quality. Exit Project, Indiana University at South Bend. Washington DC: Office of Educational Research and Improvement. (ERIC Document Reproduction Services No. ED 333 482)

Ganschow, L., Sparks, R. L., Anderson, R., Javorshy, J., Skinner, S., \& Patton, J. (1994). Differences in language learning performance among high-, average-, and low-anxious college foreign language learners. Modern Language Jour- 
nal, 78, 41-55.

Gardner, R., Lalonde, N., Moorcroft, R., \& Evers, F. T. (1987). Second language attrition: The role of motivation and use. Journal of Language and Social Psychology, 6, 29-47.

Griffee, D. (1997). Validating a questionnaire on confidence in speaking English. The JALT Journal, 19 (2), 177-197.

Griffee, D. (1998). Translating questionnaires from English into Japanese: Is it Valid? In A. Barfield, R. Betts, J. Cunningham, N. Dunn, H. Katsura, K. Kobayashi, N. Padden, N. Parry, \& M. Watanabe (Eds), On JALT98: Focus on the Classroom: Interpretations. Tokyo: JALT.

Gungle, B. W., \& Taylor, V. (1989). Writing apprehension and second language writers. In D. Johnson \& D. Roen (Eds.), Richness in writing: Empowering ESL students (pp. 235-248). New York: Longman.

Hatch, E., \& Lazaraton, A. (1991). The researcb manual. Boston: Heinle and Heinle.

Hembree, R. (1988). Correlates, causes, effects, and treatment of test anxiety. Review of Educational Research, 58, 47-77.

Henerson, M. E., Morris, L. L., \& Fitz-Gibbon, C. T. (1987). How to measure attitudes. Newbury Park, CA: Sage Publications, Inc.

Heston, J. K., \& Paterline, E. J. (1974). Unwillingness to communicate: Explication and scale development. Paper presented at the Annual Convention of the International Communication Association, New Orleans, LA.

Horwitz, E. (1986). Preliminary evidence for the reliability and validity of a foreign language anxiety scale. TESOL Quarterly, 20 (3), 559-562.

Horwitz, E. (1988). The beliefs about language learning of beginning university foreign language students. Modern Language Journal, 72, 283-294.

Horwitz, E., Horwitz, M., \& Cope, J. (1986). Foreign language classroom anxiety. Modern Language Journal, 70, 125-132.

Johnson, D. M. (1992). Approaches to research in second language learning. White Plains, NY: Longman.

Kaplan, R. B. (1966). Cultural thought patterns in intercultural education. Language Learning 16 (1), 1-20.

Kim, J., \& Mueller, C. (1978). Introduction to factor analysis: What it is and how to do it. Newbury Park, CA: Sage Publications, Inc.

Kleinmann, H. H. (1977). Avoidance behavior in adult second language acquisition. Language Learning, 27 (1), 93-107.

Kline, P. (1997). An easy guide to factor analysis. New York: Routledge.

Koch, A. \& Terrell, T. (1991). Affective reactions of foreign language students to natural approach activities and teaching techniques. In E. K. Horwitz \& D. J. Young (Eds.), Language anxiety: From theory and research to classroom implications (pp. 109-126). Englewood Cliffs, NJ: Prentice Hall.

Krashen, S. D. (1982). The Input Hypothesis. In J. E. Alatis (Ed.), Current issues in bilingual education: Georgetown University round table on languages and linguistics (pp. 168-180). Washington, DC: Georgetown University Press.

MacIntyre, P. D. (1995). How does anxiety affect second language learning? A reply to Sparks and Ganschow. Modern Language Journal, 79, 90-99. 
MacIntyre, P. D., \& Gardner, R. C. (1989). Anxiety and second language learning: Toward a theoretical clarification. Language Learning, 39 (2), 251-275.

MacIntyre, P. D., \& Gardner, R.C. (1991). Methods and results in the study of anxiety in language learning: A review of the literature. Language Learning, $41(1), 85-117$.

Macintyre, P. D., \& Gardner, R. C. (1994a). The effects of induced anxiety on three stages of cognitive processing in computerized vocabulary learning. Studies in Second Language Acquisition, 16, 1-17.

MacIntyre, P. D., \& Gardner, R. C. (1994b). The subtle effects of language anxiety on cognitive processing in the second language. Language Learning, 44 (2), 283-305.

MacIntyre, P. D, Noels, K. A., \& Clement, R. (1997). Biases in self-ratings of second language proficiency: The role of language anxiety. Language Learning, 47 (2), 265-287.

Masny, D., \& Foxall, J. (1992). Writing apprebension in L2. Washington DC: Office of Educational Research and Improvement. (ERIC Document Reproduction Service No. ED 352 844)

McCroskey, J. C. (1970). Measurement of communication-bound anxiety. Speech Monographs, 37, 269-277.

Mejias, H., Applbaum, R., Applbaum, S., \& Trotter, R. (1991). Oral communication apprehension and Hispanics: An exploration of oral communication apprehension among Mexican American students in Texas. In E. K. Horwitz \& D. J. Young (Eds.), Language anxiety: From theory and research to classroom implications (pp. 87-97). Englewood Cliffs, NJ: Prentice Hall.

Microsoft Excel 5.O (Computer software). (1985-96). Redmond, WA: Microsoft.

Powell, B. J. (1984). A comparison of students' attitudes and success in writing. Journal of Negro Education, 53 (2), 114-123.

Price, M. (1991). The subjective experience of foreign language anxiety: Interviews with anxious students. Language Anxiety: From theory and research to classroom implications. In E. K. Horwitz \& D. J. Young. (Eds.), Language anxiety: From theory and research to classroom implications (pp. 101-108). Englewood Cliffs, NJ: Prentice Hall.

Royce, J. (1963). Factors as theoretical constructs. In D.N. Jackson \& S. Messick (Eds.), Problems in buman assessment. New York: McGraw-Hill.

Selfe, C. L. (1984). The predrafting processes of four high- and four low-apprehensive writers. Research in the Teaching of English, 18 (1), 45-64.

Silva, T. (1990). Second language composition instruction: Developments, issues, and directions in ESL. In B. Kroll (Ed.), Second language writing: Research insights for the classroom. (pp. 11-23). Cambridge: Cambridge University Press.

Sparks, R. L., \& Ganschow, L. (1991). Foreign language learning differences: Affective or native language aptitude differences? Modern Language Journal, 75, 3-16.

Sparks, R. L., \& Ganschow, L. (1993a). The impact of native language learning problems on foreign language learning: Case study illustrations of the linguistic coding deficit hypothesis. Modern Language Journal, 77, 58-74. 
Sparks, R. L. \& Ganschow, L. (1993b). Searching for the cognitive locus of foreign language learning difficulties: Linking first and second language learning. Modern Language Journal, 77, 289-302.

Sparks, R. L., \& Ganschow, L. (1995). A strong inference approach to causal factors in foreign language learning: A response to MacIntyre. Modern Language Journal. 79, 235-248.

SPSS Inc. (1989-1995). SPSS Statistical Software Package (Release 6.1.1.) [Computer Softwarel. Chicago: SPSS Inc.

Steinberg, F., \& Horwitz, E. (1986). The effects of induced anxiety on the denotative and interpretive content of second language speech. TESOL Quarterly, 20 (1), 131-36.

Tabachnick, B. \& Fidell, L. (1996). Using Multivariate Statistics (3rd ed.). New York: Harper Collins.

Tobias, S. (1986). Anxiety and cognitive processing of instruction. In R. Schwarzer (Ed.), Self-related cognition in anxiety and motivation (pp. 35-54). Hillsdale, NJ: Erlbaum.

Thurstone, L. (1947). Multiple factor analysis: A development and expansion of vectors of the mind. Chicago: University of Chicago Press.

Wheeles, L. R. (1974). An investigation of receiver-apprebension and social context dimensions of communication apprehension. Paper presented at the Annual Convention of the International Communication Association, New Orleans, LA.

Young, D. (1990). An investigation of students' perspectives on anxiety and speaking. Foreign Language Annals, 23, 539-553.

(Received June 28, 1999; revised December 14, 1999)

\section{Appendix A}

\section{Modified Daly-Miller Writing Apprehension Questionnaire, English Version}

Directions: Below are a series of statements about writing in English. There are no right or wrong answers to these statements. Please indicate the degree to which each statement applies to you when writing in English by circling whether you (1) strongly agree, (2) agree, (3) are uncertain, (4) disagree, or (5) strongly disagree with the statement. While some of these statements may seem repetitious, take your time and try to be as honest as possible. Thank you for your cooperation in this matter.

strongly agree 1

1. I avoid writing.

2. I have no fear of my writing being evaluated.

3. I look forward to writing down my ideas.

4. I am afraid of writing essays when I know they will be evaluated.

\begin{tabular}{|c|c|c|c|c|}
\hline \multirow{2}{*}{$\begin{array}{l}\text { disagree } \\
4\end{array}$} & \multicolumn{4}{|c|}{$\begin{array}{c}\text { strongly disagree } \\
5\end{array}$} \\
\hline & 2 & 3 & & \\
\hline & 2 & 3 & 4 & \\
\hline & 2 & 3 & & \\
\hline 1 & 2 & 3 & & \\
\hline
\end{tabular}


5. Taking a composition course is a very frightening experience. $\quad \begin{array}{llllll}1 & 2 & 3 & 4 & 5\end{array}$

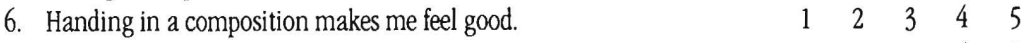

7. My mind seems to go blank when I start to work on a composition. $\quad \begin{array}{llllll}1 & 2 & 3 & 4 & 5\end{array}$

8. Expressing ideas through writing seems to be a waste of time. $\quad \begin{array}{llllll}1 & 2 & 3 & 4 & 5\end{array}$

9. I would enjoy submitting my writing to magazines for evaluation and publication.

10. I like to write my ideas down. $\begin{array}{lllll}1 & 2 & 3 & 4 & 5\end{array}$

11. I feel confident in my ability to clearly express my ideas in writing. $\quad \begin{array}{llllll}1 & 2 & 3 & 4 & 5\end{array}$

12. I like to have my friends read what I have written. $\quad 1 \begin{array}{lllll}1 & 2 & 3 & 4 & 5\end{array}$

13. I'm nervous about writing.

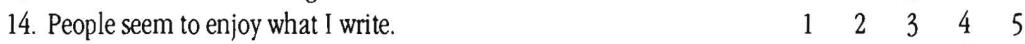

15. I enjoy writing. $\quad \begin{array}{llllll}1 & 2 & 3 & 4 & 5\end{array}$

16. I never seem to be able to clearly write down my ideas. $\quad 1 \quad 2 \quad 3 \quad 4 \quad 5$

17. Writing is a lot of fun. $\quad \begin{array}{lllll}1 & 2 & 3 & 4 & 5\end{array}$

18. I expect to do poorly in composition classes even before I enter them. $\begin{array}{llllll}1 & 2 & 3 & 4 & 5\end{array}$

19. I like seeing my thoughts on paper. $\quad \begin{array}{llllll} & 2 & 3 & 4 & 5\end{array}$

20. Discussing my writing with others is an enjoyable experience. $\quad \begin{array}{llllll}1 & 2 & 3 & 4 & 5\end{array}$

21. I have a terrible time organizing my ideas in a composition course. $\begin{array}{llllll}1 & 2 & 3 & 4 & 5\end{array}$

22. When I hand in a composition I know I'm going to do poorly. $\quad \begin{array}{llllll}1 & 2 & 3 & 4 & 5\end{array}$

23. It's easy for me to write good compositions. $\quad 1 \begin{array}{lllll}2 & 3 & 4 & 5\end{array}$

24. I don't think I write as well as most other people. $\quad 1 \quad 223045$

25. I don't like my compositions to be evaluated. $\quad 1 \quad 2 \quad 3 \quad 4 \quad 5$

26. I'm no good at writing. $\quad 1 \quad 2 \quad 3 \quad 4 \quad 5$

[Note: modified portion of the DM-WAT begins here]

In high school how much writing experience did you have with the following:

\begin{tabular}{cccccc}
$4=$ very frequently & $3=$ frequently & \multicolumn{2}{c}{2 = infrequently $\quad 1=$ not at all } \\
Sentences & 4 & 3 & 2 & 1 & \\
Paragraphs & 4 & 3 & 2 & 1 & \\
Essays & 4 & 3 & 2 & 1
\end{tabular}

Did you study abroad in an academic school? If yes, for how long?

Name: Student ID: Class: 


\section{Appendix B \\ 英語で文章を费くことについての意識調査}

I．下記の英語で文章を書くことについての質問に答えてください。正しいあるいはまち がった答えはありません。各々の項目であなたが英語で文章を畫くときに感ずるとおり に、（1）非常にそう思う（2）そう思う（3）わからない（4）そうは思わない（5） そ うとは全く思わない のいずれかを○でかこんでください。いくつかの項目は重複してい るように思えるかもしれませんが、よく考えて正直に答えてください。ご協力ありがとう ございます。

非常にそう思う そう思う わからない そうは思わない そうとは全く思わない

$\begin{array}{lllll}1 & 2 & 3 & 4 & 5\end{array}$

1. 英語で䡆くことを避ける。

2. 英語で著いた文章を評価されることを大変恐れる。

3. 自分の意見を英語で害くことを楽しみにしている。 5

4. 英語で書いた文章を評価されると知っている時、英語で文章を書くのは嫌である。

5. 英語で考えを書き下ろすことは好きである。

6. 英語で考えを莗き表す能力が自分にはあると自信がある。 $\begin{array}{lllll}1 & 2 & 3 & 4 & 5\end{array}$

7. 英語で書いた自分の文章を友達に読んでもらうのは好きである。

8. 英語で文章を菄くことは楽しい。

9. 英語で自分の考えをうまくまとめることができるとは思えない。

10. 英語で文章を書くのは大変楽しい。

11. 自分が英語で書いた文章上に自分の考えを見るのは好きである。1 $2 \begin{array}{lllll}2 & 3 & 4 & 5\end{array}$

I2. 自分が英語で寒いた文章を他人と話し合うのは楽しいことである。

13. 英語で軎いた作文を提出するとき、よい成䅡はとれないとわかっている。

14. 自分は他の人ほど上手に英語で文章を書けるとは思わない。

15. 自分が春いた英語の文章を評価されるのは嫌である。

16. 英語で文章を書くのは得意ではありません。 $\begin{array}{lllll}1 & 2 & 3 & 4 & 5\end{array}$

II. 次の項目に答えてください。

1. 高校時代にあなたは英語で文章を書きましたか。 $\begin{array}{cccc}\text { 大変よく费いた } & \text { よく昰いた } & \text { あまり春かなかった } & \text { 全然费かなかった } \\ 4 & 3 & 2 & 1\end{array}$

$\begin{array}{lllll}\text { sentences } & 4 & 3 & 2 & 1 \\ \text { paragraphs } & 4 & 3 & 2 & 1 \\ \text { essays } & 4 & 3 & 2 & 1\end{array}$

2. 高校時代に英語圏の高校へ正規留学したことがありますか。はい いいえ はいと答えた方はどのくらいの期間ですか。 氏名： 学籍番号 : 